\title{
Effects of Corporate Social Responsibility and Performative Actions on Retailer Legitimacy and Consumer Loyalty
}

\author{
Jiyoung $\mathrm{Kim}^{1} \&$ Sejin $\mathrm{Ha}^{2}$ \\ ${ }^{1}$ Department of Merchandising and Digital Retailing, College of Merchandising, Hospitality and Toursim, \\ University of North Texas, Denton, TX, United States \\ ${ }^{2}$ Department of Retail, Hospitality \& Tourism Management, College of Education, Health and Human Sciences, \\ The University of Tennessee, Knoxville, TN, United States
}

Correspondence: Jiyoung Kim, College of Merchandising, Hospitality and Toursim, University of North Texas, Denton, TX, United States. E-mail: jiyoung.kim@unt.edu

Received: June 15, 2020 Accepted: July 17, $2020 \quad$ Online Published: July 22, 2020

doi:10.5539/ijms.v12n3p41 URL: https://doi.org/10.5539/ijms.v12n3p41

\begin{abstract}
The purpose of this research is to propose and empirically test a research framework that illustrates how Corporate Social Responsibility (CSR) and performative action influence consumer's perception of organizational legitimacy and loyalty intention, based on institutional theory. Further, we examine the interaction effect of CSR and performative action on organizational legitimacy, where we propose that the effect of CSR on legitimacy becomes amplified when performative action is high. To test the hypotheses, a total of 222 usable data were collected from consumers residing in a metropolitan area. Hypotheses were tested using Moderated Structural Equation Modelling. The study result reveals that both CSR and performative action are critical in establishing organizational legitimacy. Further, the result shows that the interaction coefficient for the interaction is significant that the relationship between CSR performance and legitimacy intensifies when performative action is high. The research outcome provides valuable implications to practitioners that legitimacy from the institutional environment and loyalty from the economic environment has to exist as separate domains for business to survive.
\end{abstract}

Keywords: CSR, institutional theory, legitimacy, loyalty, retail

\section{Introduction}

Corporate Social Responsibility (CSR), generally defined as pro-social corporate endeavors (Sen \& Bhattacharya, 2001), has become one of the key business priorities in the global retail and consumer goods sector. Past empirical studies have examined the effects of CSR on several consumer behavioral responses, such as company evaluation (e.g., Hilderbrand et al., 2017), attitude toward the company (e.g., Wei et al., 2018), customer satisfaction and market value (e.g., Luo \& Bhattacharya, 2006), brand loyalty (Marin \& Ruiz, 2007), stakeholder relationships (e.g., Bhattacharya, Korschun, \& Sen, 2009; Sen, Bhattacharya, \& Korschun, 2006), product responses (e.g., Berens, van Riel \& van Bruggen, 2005; Brown \& Dacin, 1997; Gurhan-Canli \& Batra, 2004), customer donations (e.g., Lichtenstein, Drumwright, \& Braig, 2004), and brand evaluations in a product-harm crisis (Klein \& Dawar, 2004). While previous research has focused on CSR and its influences on organizations, little research has examined CSR practice within an institutional system contributing to organizational legitimacy, and further, consumer loyalty intention.

The institutional theory views an organization as a social entity expected to accommodate societal norms, symbols, beliefs, and rituals prevalent in the social structure rather than purely focusing on material or strategic output (DiMaggio \& Powell, 1991). The crux of the theory concerns the institutional system as a class of cultural elements and symbols to which organizations must conform to receive support and legitimacy (DiMaggio \& Powell, 1991). Research on institutional theory stresses two components crucial to organizational survival: legitimacy and congruence between strategic performance and institutional systems/norms (Arnold, Handelman, \& Tigert, 1996). More specifically, organizational legitimacy is developed as a result of evaluations by the social actors (e.g., consumers), who compare an organization's actions and practices to intra-institutional norms (Suchman, 1995) where norms represent "rules of procedures that actors employ flexibly and reflexively to assure themselves and those around them that their behavior is reasonable" (DiMaggio \& Powell, 1991, p. 20). If 
values implied by an organization's activities meet its institutional norms, the organization is considered legitimate by the social actors (Suchman, 1995). When an organization has achieved legitimacy, it obtains justification to constituents for its existence, thus earning further support from the constituents (Handelman \& Arnold, 1999). This motivates organizations to establish congruence between their strategic activities and institutional norms in the larger social systems of which they are a part of long-term support and survival.

Anderson (1982) indicates that for an organization to survive, "the organization must maintain a coalition of parties willing to 'legitimize' its existence" (p. 19), where these "parties" include customers, stockholders, lenders, employees, and community. For example, consumer constituency often believes companies should offer low prices, while community constituency values supporting local charities and causes. As an individual consumer is often part of both consumer constituency and community constituency (Arnold, Handelman, \& Tigert, 1996), he/she legitimizes a company based on diverse sets of norms, including task-oriented norms (e.g., performative action) as well as the social norm (e.g., CSR practice).

Therefore, this study intends to offer theoretical contributions to the institutional theory literature by taking both performative action and CSR practice into account as critical factors that predict consumer legitimization and support toward a company. The purpose of this research is to address the void in the previous literature by proposing and empirically testing a research model that illustrates 1) the effect of CSR practice and performative action on consumer's perception of legitimacy and loyalty intention toward the company, and 2) the interaction effect of CSR and performative action on legitimacy, where we propose that the effect of CSR on legitimacy is amplified when performative action is high.

\section{Literature Review}

\subsection{Institutional Environment}

Institutional theory has been applied to explain many aspects of public policy and management in sociology, political science, and economics (Heikkila \& Isett, 2004). Different fields share the common basic notion but are different in their approaches. Generally, all fields view institutions as the mechanisms that guide behavior when selecting among choices of action. It is thus agreed that decision making cannot be explained accurately without considering institutional contexts (Heikkila \& Isett, 2004). However, decision-making approaches vary across fields, especially between the rational choice perspective and the sociology perspective (Heikkila \& Isett, 2004). In the fields of political science and economics, the institutional theory is based on rational choice institutionalism and focuses on how rules and structures limit or authorize certain actions (Hall \& Taylor, 1996). On the other hand, sociologists view institutions as being endogenous to the social actors (Heikkila \& Isett, 2004) and emphasize how socially accepted norms and standardized practices form behavior (DiMaggio \& Powell, 1991). Of these two theoretical lenses, the sociological perspective has been particularly powerful in explaining how institutions shape choices made by organizations where the choices do not follow the efficiency maximizing decision (Heikkila \& Isett, 2004). This study builds on the sociological point of view since we are particularly interested in how companies should base their operational actions upon social norms and values that are considered important by the constituents within the institutional environment.

The institutional theory describes that individuals process information through subconscious norms and heuristics defined by their society when evaluating organizations (Heikkila \& Isett, 2004). While organizations are obligated to meet task-oriented demands (e.g., lowering the price, enhancing product quality) (Handelman $\&$ Arnold, 1999), the institutional viewpoint acknowledges the importance of an institutional environment where norms act as unwritten rules of proper social conduct to which organizations must adhere (DiMaggio, 1988; Scott, 1987).

Institutional theory connects organizational actions, including institutional action (i.e., CSR practices) and performative action, to the values and norms of a society in which an organization operates (Deegan, 2009). This connection ultimately motivates an organization to gain and maintain its legitimacy within the institutional system for long-term survival. According to Handelman and Arnold (1999), institutional action is defined as any activity that demonstrates the retailer's adherence to salient normative rules of acceptable social conduct. Meanwhile, performative action concerns tangible actions that aim to accomplish functional, measurable, and economic benefits.

Institutional theorists view legitimacy as an integral part of every business that seeks to justify its existence within the society (Cheit, 1964). Organizational legitimacy, as a status granted by a society system (Ashforth \& Gibbs, 1990), is defined as the "generalized perception or assumption that the actions of an entity are desirable, proper, or appropriate within a social system" (Suchman, 1995, p. 574). Parsons (1960) describes legitimacy as the "appraisal of action in terms of shared or common values in the context of the involvement of the action in 
the social system" $(1960$, p. 175). He notes that since organizations operate in a larger social system and utilize resources that might be otherwise allocated, the use of these resources must be accepted as legitimate by the social system. Therefore, organizations are legitimate to the extent that their activities are congruent with the norms of the institutional environment.

\subsection{CSR Practice, Performative Action, and Organizational Legitimacy}

Organizations gain legitimacy among members of each constituency by adhering to norms relevant to the members that present different sets of norms (Arnold, Handelman, \& Tigert, 1996). According to institutional theory, there are two conceptual elements of legitimation, based on different sets of norms that individual constituents use to evaluate the organizations against. First, an organization will achieve pragmatic legitimacy based on the need-satisfying ability of an organization (Suchman, 1995). For example, a consumer who is looking to buy a shirt for a reasonable price will grant legitimacy to a store that provides the right shirt at the right price, as that store demonstrates adherence to the "norms of competition" (Handelman \& Arnold, 1999). However, an organization cannot rely solely on pragmatic legitimacy for long-term support, as pragmatic legitimacy is susceptible to short-term shifts in consumer tastes, direct threats from competition, and other self-interested manipulations (Suchman, 1995). Organizations, therefore, must seek social legitimacy, or "moral legitimacy" as referred by Suchman (1995) (Handelman \& Arnold, 1999) that "reflects a positive normative evaluation of the organization and its activities [based on a] prosocial logic that differs fundamentally from narrow self- interest" (Suchman, 1995, p. 579). With social legitimacy, the evaluation of an organization is based on prosocial logic where more importance is put on the welfare of the community and society.

While there exist conceptual differences in pragmatic and social legitimacy, it is difficult to argue that these are two separate constructs (Handelman \& Arnold, 1999). "[A]udience perceptions of 'rightness' often unconsciously fuse the good of the evaluator with the good of society as a whole" (Suchman, 1995, p. 579). Being part of both consumer constituency and community constituency (Arnold, Handelman, \& Tigert, 1996), an individual consumer may decide that the company that adheres best offers the lowest price is doing society a favor. Therefore, we propose that the company's strategic action based on the two separate sets of norms (i.e., performative action and CSR activities) leads to legitimacy, based on the notion of pragmatic and social legitimacy conceptualized as two elements of the legitimacy construct.

Following the logic of the institutional theory, several studies document that consumers rely on CSR activities in determining whether or not the business is legitimate. Cheit (1964) argues that an increased level of interest on CSR has led businesses to seek legitimacy through their social norm-based actions. Arnold, Kozinets, and Handelman (2001) conclude that advertising conveying conformance to broadly-held social norms is instrumental in gaining legitimacy for retailers like Walmart with U.S. consumers. Previous research has proved that noneconomic actions such as urban renewal, support for the performing arts, and support for assisting the disadvantaged, as methods for businesses to gain legitimacy (Schlusberg, 1969; Votaw \& Sethi, 1969). When an organization's actions are evaluated by the society members as consistent with the social norms and betterment of society, the organization gains legitimacy and further is rewarded with support (Elsbach, 1994). Therefore, it is hypothesized that:

\section{H1. Consumers' positive evaluation of a company's CSR practice will increase the retailer's legitimacy.}

As discussed earlier, a business must satisfy different members of various constituents, which include consumers, employees, and communities to achieve legitimization. While the company aims to comply with these constituent's norms, it also faces challenges due to varied and often conflicting norms. Further, one individual simultaneously belongs to many different constituencies (Arnold, Handelman, \& Tigert, 1996). For example, a consumer is not only a customer, but may also be a member of a community, a member of a family, a citizen of a nation, and an employee of a company. Having such various roles guides this individual to carry different norms and more likely to grant legitimacy to those who "have our best interests at heart" (Suchman, 1995, p. 578) while "the best interest" of individual consumers is not defined by one constituent party. In other words, a consumer will be looking for a company to demonstrate compliance with various sets of norms that may include task-oriented norms (e.g., offering low prices, wide assortment, and convenient location), in addition to prosocial norms (e.g., supporting local charities). Handelman and Arnold (1999) refer to such actions responding to the economic and operational needs of the task-oriented environment as "performative actions."

According to Handelman and Arnold (1999), retailers should adhere to accomplish measurable objectives through tangible actions such as an assortment of merchandise, competitive prices, and convenient location. They define such attributes as performative as these actions provide consumers with economic benefits (Handelman \& Arnold, 1999). This study adopts such a concept of performative action of Handelman and 
Arnold (1999) and proposes that legitimacy is earned not only through CSR actions but also through the company's performative action.

H2. Consumers' positive evaluation of a company's performative action will increase the retailer's legitimacy.

\subsection{Organizational Legitimacy and Loyalty Intention}

Previous research grounded on institutional theory has found that that various types of support for organizations are determined as a result of their being granted legitimacy (Suchman, 1995). When consumers perceive a company to be complying well with the institutional norms, they will be willing to grant legitimacy and further support the company to exist within the society. Thus, companies seek to achieve legitimacy from those constituents that have the power and ability to support the organization (Meyer \& Scott, 1992b).

Based on the institutional theory perspective, companies rely on many other types of support from constituents for their long-term survival (Handelman \& Arnold, 1999). In the short term, the purchase intention of the consumer would be one form of support (Mohr, Webb, \& Harris, 2005). When looking at the long run, loyalty is another (Mejri \& Bhatli, 2014). Customer loyalty is defined as customers' deeply held commitment to a product or service, causing repeated purchase despite changes in purchase situations and a competitive offer from another company (Oliver, 1997). According to Shrinivasan et al. (2002), both attitudinal and behavioral aspect is incorporated into the concept of customer loyalty. A loyal consumer tends to have commitment and attachment towards the brand and is not easily distracted to a slightly more attractive alternative even while paying premium prices at the focal company (Shankar, Smith, \& Rangaswamy, 2003). Therefore, this study proposes that consumers manifest their legitimacy toward the company with long-term support, which is represented with loyalty intention.

H3. The legitimacy of the retailer will increase consumer loyalty intention toward the retailer.

\subsection{The Interactive Effect Between CSR and Performative Action}

While the relationship between performative actions and business outcomes is well documented in previous literature, findings on the effect of CSR practice on consumer behavior are not consistent (e.g., Berens et al., 2005; Gurhan-Canli \& Batra, 2004; Sen \& Bhattacharya, 2001). These mixed results from prior studies indicate that the effects of CSR practice could be conditional on other factors. Brown and Dacin (1997) explain that CSR association tends to have a weaker effect on business outcomes as CSR information is often less diagnostic or directly related to the quality of the product/service offered, compared to Corporate Ability (CA) association which directly relates to a company's ability to offer high-quality products. Further, Sen and Bhattacharya's study (2001) indicates that the lack of positive effect of CSR is due to consumer perception on Corporate Ability (CA)-CSR trade-off, a belief that if a company invests more in CSR, the company would compromise its CA. Therefore, we propose that the effect of CSR action on legitimacy will be strengthened if the company is perceived as positive in its performative action. Although consumers' perceptions of strong CSR action of a company lead to legitimization, CSR's effect on legitimacy is likely to be enhanced for companies that enjoy stronger performative action.

H4. Performative action and CSR have an interaction effect on legitimacy such that as consumers' positive evaluation of a company's performative action increases, CSR has a stronger effect on legitimacy.

Figure 1 presents the conceptual model illustrating the research hypotheses.

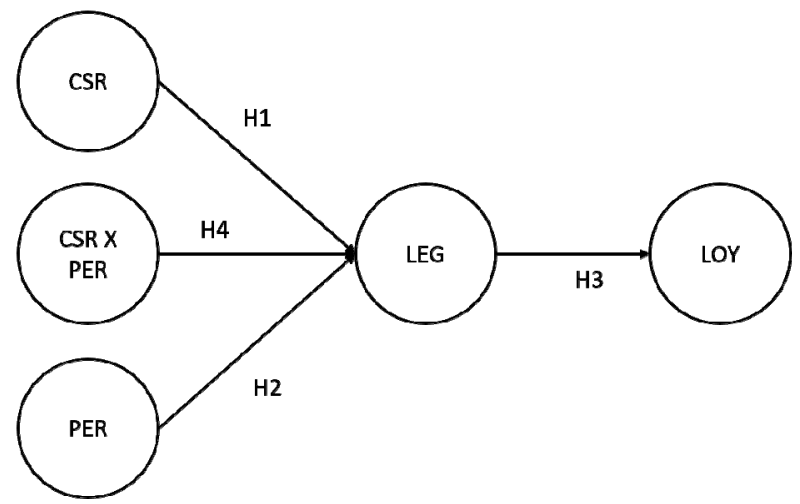

Figure 1. Proposed research model

Note. CSR corporate social responsibility practice, PER performative action, LEG organizational legitimacy, LOY loyalty intention. 


\section{Method}

\subsection{Measures}

The research constructs (i.e., CSR practice, performative action, organizational legitimacy, and loyalty intention) are measured with existing scales established and validated in previous studies. All items, unless particularly specified, used a 5 -point scale $(1=$ strongly disagree, $5=$ strongly agree $)$. For CSR practice, four items measuring institutional actions are adapted from Handelman and Arnold (1999), who used institutional theory to study the interaction between marketing actions and social dimensions in earning consumer support. Their measures intended to assess the organization's behavior that is congruent with accepted social values and norms within the framework of institutional theory. These measures are deemed appropriate for our study of CSR as they focused on the organization's adherence to the social norm within the institutional environment in contrast to the activities targeted the task-oriented norm. Seven items for performative actions are adapted from Arnold, Handelman, and Tigert (1996) who studied the effect of symbolic and performative action on store choice. A set of performance attributes on location, price assortment (e.g., ...easiest to get from your home? Lowest everyday price?) from Arnold et al. (1996) is converted to a Likert type scale to reflect the performative action within the task-oriented environment. For organizational legitimacy, four items are adapted from Elsbach (1994) that reflects the external endorsement of the company. Six items for loyalty intention are adapted from the measure by Srinivasan et al. (2002).

\subsection{Data Collection and Sample}

Data were collected through a mail survey of consumers residing in two large metropolitan areas in the U.S. In completing a survey, participants were instructed to answer survey questions based on their perceptions of, experience with, and evaluation of a general merchandise retailer randomly assigned among three national chains (i.e., Walmart, Kroger, and Target). This tactic allowed us to control potential bias that might lie in focal company selection, as the extent and type of CSR practices and performative actions by these companies varied. Compared to when participants were asked to name their most recently or frequently visited store, researchers were able to get a varying spectrum of consumer responses with this approach. The three companies, in particular, were chosen as they operate stores across all local communities that grant participants' familiarity with performative and CSR practices of the assigned retailer. The survey was modified to fit each of the three retailers.

The survey proceeded in three phases. First, together with a brief introduction about research, respondents answered general information about their shopping experiences with an assigned retailer's stores including the frequency of store visits per month. Next, respondents evaluated questions as to performative action, CSR practice, legitimization, and loyalty intention toward the retailer's stores. Last, questions regarding demographic information were asked (e.g., age, gender, marital status, annual household income, education).

The mail survey was administered using a modified Dillman mail survey technique (Dillman, 2000). First, an introductory letter, the questionnaire, and a return envelope were mailed to potential participants on the mailing list. The letter explained the survey and the procedure. Respondents were asked to self-complete the survey and mail the completed questionnaire in the enclosed, prepaid return envelope. To preserve confidentiality, the instruction also advised respondents not to write names and addresses on the return envelope. Follow-up postcards were mailed one week after the initial mailing of the questionnaire, and the third reminder including a set of the introductory letter, the questionnaire, and return envelope were generated and mailed after two weeks.

Out of the total sample of 5,400 potential respondents approached, 297 returned the completed survey (response rate $=5.5 \%$ ). Removing 75 cases due to missing data resulted in a final set of 222 usable responses. The sample consisted of $54.1 \%$ female $(n=120)$ and $45.9 \%$ male $(n=102)$ with an average age of 48 , ranging from 19 to 82 years old. Over $60 \%$ of the sample $(n=137)$ was married and $28.6 \%$ were single $(n=63)$. Household income varied in all categories. Approximately $43.2 \%$ of respondents reported annual income less than $\$ 50,000,39.2 \%$ between $\$ 50,000$ and $\$ 100,000$, and $17.2 \%$ greater than $\$ 100,000$. An education profile indicated the sample being well-educated: Half of the respondents $(49.8 \%)$ have earned a bachelor's degree or higher. Regarding the frequency of shopping at a given retail store per month, $44.6 \%$ of respondents indicated between 1 and 5 times, $29.6 \%$ less than 1 time, and $16.7 \%$ between 6 and 10 times.

To test for nonresponse bias, a comparative analysis between early respondents and later respondents was examined on key demographic characteristics and research variables (Armstrong \& Overton, 1977). No significant differences between the two groups were detected suggesting that nonresponse bias was not an issue. All scales demonstrated high internal reliability of each construct with Cronbach's alphas above 0.70 . 


\subsection{Measurement Model}

A two-step approach of Structural Equation Modelling (SEM) was used to analyze the measurement model and test hypotheses in AMOS 20.0 with maximum likelihood (ML) estimation (Anderson \& Garbing, 1988). The proposed model included four latent constructs measured with multi-item scales corresponding to a total of 21 indicators. Confirmatory factor analysis (CFA) with the original measurement model produced an unsatisfactory fit with the data: $\chi^{2}=776.78, d f=179, \chi^{2} / d f=4.34$, Standardized RMR $=0.10$, IFI $=0.82$, TLI $=0.78$, CFI $=$ 0.81 , RMSEA $=0.12$ [90\% CI: $0.11,0.14]$. The model was re-specified to correct specification errors that were likely to be reasons for the lack of correspondence between the proposed model and the true model of the research variables (MacCallum, 1986). In doing so, both statistical and theoretical considerations were taken into account (Anderson \& Gerbing, 1988; MacCallum, 1986), thereby resulting in the deletion of four items from performative action, one item from legitimization, and one item from loyalty intention.

CFA with the respecified model suggested an acceptable fit of the model to the data: $\chi^{2}=199.81, d f=84, \chi^{2} / \mathrm{df}=$ 2.38, Standardized RMR $=0.05, \mathrm{IFI}=0.95, \mathrm{TLI}=0.94, \mathrm{CFI}=0.95, \mathrm{RMSEA}=0.08[90 \% \mathrm{CI}: 0.06,0.09]$. The psychometric properties of the fitted model were examined (Fornell \& Larcker, 1981). As presented in Tables 1 and 2, the measurement model demonstrated support for internal reliability, convergent validity, and discriminant validity. Evidence of convergent validity existed as all factor loadings were significant and the average variance extracted (AVE) in indicators by their corresponding constructs exceeded 0.50, and composite reliability was equal to or higher than 0.60 . Discriminant validity was established as the AVE estimate of each construct was greater than the squared multiple correlation estimates between all possible pairs of constructs.

Table 1. Confirmatory factor analysis

\begin{tabular}{ll}
\hline Constructitems & Std. factor loading \\
\hline CSR Practice ( $\alpha=0.94, \mathrm{CR}=.89$, Var $=66.47 \%)$ & 0.865 \\
This retailer (local WAL MART store) sets an example for how other retailers should operate their businesses & 0.798 \\
This retailer is committed to meeting the standards that our community expects of locally owned retailers & 0.864 \\
This retailer sets an example for how local retailers should behave & 0.726 \\
The owner of this retail store believes in "playing by the rules" and following accepted operating guidelines & \\
Performative Action $(\alpha=0.72, \mathrm{CR}=.78$, Var. $=54.43 \%)$ & 0.711 \\
This retailer offers competitive prices & 0.859 \\
This retailer offers attractive prices for special promotions and sales & 0.624 \\
This retailer offers a competitive overall selection of merchandise & \\
Legitimization $(\alpha=0.81, \mathrm{CR}=.86$, Var. $=67.59 \%)$ & 0.859 \\
Our community members approve of this retailer's operating procedures & 0.772 \\
Most of our community members would approve of this retailer if asked their opinion & 0.833 \\
Our community members approve of this retailer's operating practices & \\
Loyalty Intention $(\alpha=0.90, \mathrm{CR}=.87$, Var. $=58.44 \%)$ & 0.725 \\
I consider this retailer my first choice as a place to buy & 0.679 \\
I will do more business with this retailer in the next few years & 0.875 \\
I say positive things about this retailer to other people & 0.922 \\
I recommend this retailer to community members who seek my advice & 0.917 \\
I encourage friends and relatives to do business with this retailer &
\end{tabular}

Table 2. Convergent and discriminant validity

\begin{tabular}{llllll}
\hline & Mean (SD) & CSR & Performative action & Legitimization & Loyalty intention \\
\hline CSR & $3.41(0.67)$ & .66 & .24 & .58 & .62 \\
Performative action & $3.87(0.67)$ & & .54 & .20 & .29 \\
Legitimization & $3.57(0.60)$ & & & .68 & .41 \\
Loyalty intention & $3.43(0.84)$ & & & & .63 \\
\hline
\end{tabular}

Note. The numbers in diagonal are the average variance extracted by each construct. The numbers above the diagonal show the squared correlation coefficients between the constructs.

\section{Results}

Moderated Structural Equation Modelling (Ping, 1995) was performed to test the hypotheses using AMOS 20.0 with the covariance matrix and ML estimation. The structural model fitted the data well: $\chi^{2}=161.936, d f=92$, $\chi^{2} / d f=1.77$, Standardized RMR $=0.037$, IFI $=0.972$, TLI $=0.963$, CFI $=0.972$, RMSEA $=0.059[90 \%$ 
CI: .043, .073]. Consumer's evaluations of CSR activities $(\beta=.789 . p<.001)$ as well as performative action $(\beta$ $=.200 . p<.001)$ positively predicted legitimacy, supporting hypotheses 1 and 2 . In addition, our research result revealed that CSR had a stronger effect on organizational legitimacy compared to performative action. Further, consistent with hypothesis 3 , legitimacy led to positive loyalty intention $(\beta=.823 . p<.001)$. Figure 2 presents the result.

Hypothesis 4 proposed that performative action would moderate the positive effect of CSR on legitimacy, where the effect would amplify when performative action is high. Result showed that the interaction coefficient for the interaction was significant $(\beta=.01 p<.001)$. Further examining the result of the simple slopes test, it indicated that there was a relatively weak interaction effect. While the relationship between CSR and engagement had a stronger effect on legitimacy $(\beta=.794, t=2.37, p<.05)$ when performative action was high than when performative action was low $(\beta=.792, t=2.99, p<.05)$, the $\beta$ values were similar. See Figure 3 for the interaction plot.

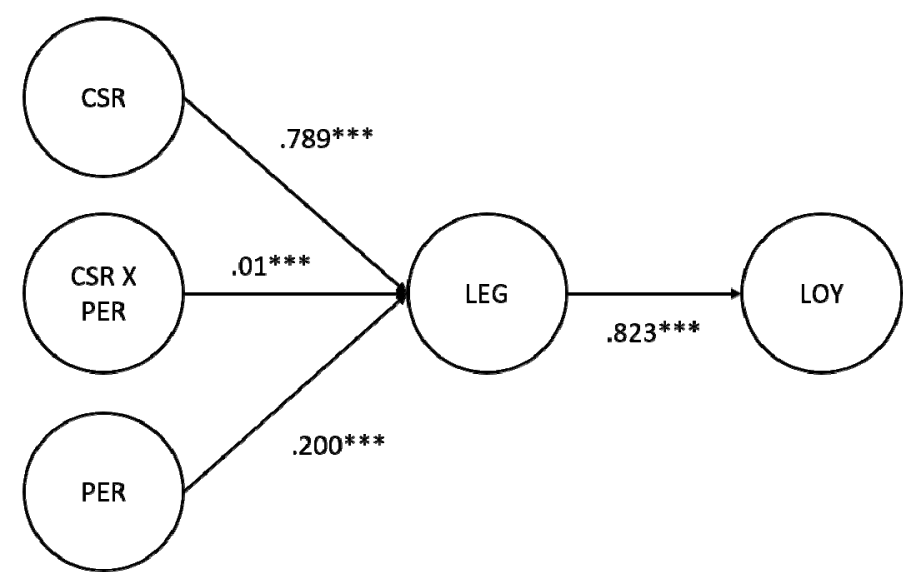

Figure 2. Moderated Structural Equation Model result

Note. ${ }^{* *} p<0.001$, Coefficients are standardized estimates.

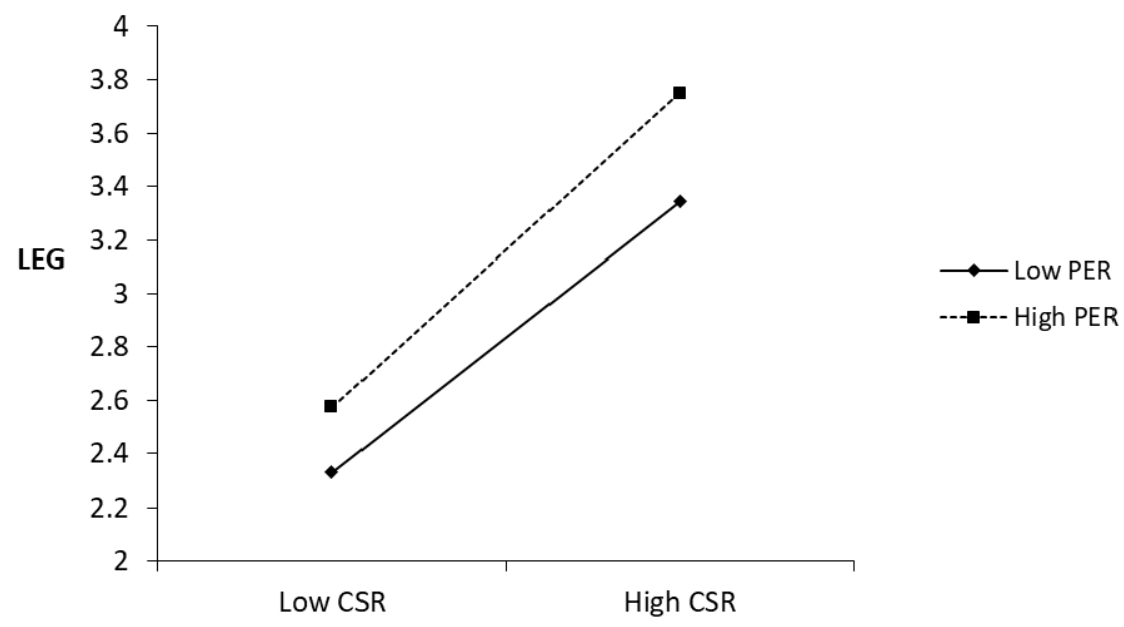

Figure 3. Interaction between CSR and performative action on legitimacy

\section{Discussion}

\subsection{Conclusion and Implications}

In a capitalistic society, many consumers invest their time and money in organizations that return that same favor into society. When brand parity occurs, individuals rely on other factors to make purchase decisions, including 
moral and cultural views that benefit themselves as well as other members of the society. Additionally, prior literature has brought forth the need for organizations to legitimize their existence to consumers to differentiate from the crowd and build brand equity (Arnold, Handelman, \& Tigert, 1996). Extending the previous studies on institutional theory, this study examined how CSR and performative action influence consumer's perception of organizational and loyalty intention, based on institutional theory.

First, the study result revealed that both CSR and performative action contribute to the achievement of organizational legitimacy. This result is in line with the proposition of other researchers (e.g., Parsons, 1960), who argue that companies gain legitimacy by accepting both customer and social norms. Companies are paying increased attention to corporate branding (e.g., Knox \& Bickerton, 2003) and corporate marketing (Balmer \& Greyser, 2006; He \& Balmer, 2007), coupling their brand image with various social performance such as CSR initiatives, in hopes of a better market and financial performance (He \& Yi, 2011). On the other hand, companies are increasing their investments/efforts in product and service performance for a favorable brand attitude, better customer service experience, satisfaction, and loyalty. This study incorporates both the prosocial norm (i.e., CSR) and task-oriented norms (i.e., performative action) within the institutional system in formulating organizational legitimacy and loyalty to form an integrative model of company performance. As social institutions, companies should cater to various sets of institutional norm, as they aim for organizational sustainability from both social and organizational perspectives.

In addition, our research result found a significant interaction effect between CSR and performative action, yet the effect was weak. CSR has a slightly stronger effect on organizational legitimacy compared to performative action. As there is increasing pressure to implement CSR as a business discipline (Ranjan, Chase, \& Karim, 2015), consumers may grant legitimacy with evaluation skewed toward performance that meets the social norms but not the task-oriented norms. Especially when other companies in the institutional environment excel in CSR performance, the evaluation of the legitimacy of the target company may get affected. Anagnostou and Ingenbleek (2015) studied how the existence of an organic Fairtrade product produced with socially responsible guidelines changed consumers' perception of other mainstream products. The study result revealed that with the introduction of the product labeled with Organic-Fair Trade, perceptions of social and environmental performance as well as product quality of mainstream products significantly decreased which led to challenging the legitimacy of the mainstream product. In other words, while the performative action of the mainstream products did not change, the introduction of competitors with better CSR performance led consumers to alter their perception toward the legitimacy of the mainstream product. This indicates that increased awareness and gradual change in the ruling norms around the society may eventually lead consumers to grant legitimacy based more on CSR actions compared to performative actions. While Arnold and his colleagues (2001) highlighted that both economic and moral norms play a role in granting organizational legitimacy, the development of proactive CSR programs prevalent in the industry might alter the legitimization process to put more weight on CSR action.

Further, we examined the interaction effect of CSR and performative action on legitimacy, where the effect of CSR on legitimacy becomes stronger when performative action is high. While most prior CSR research focused on independent effect of CSR and/or performative action on positive business outcomes, this study proposed that social and profit motives should not contradict each other, but rather have complementary outcomes. Previous research found that the effects of CSR on product evaluation and brand attitude tend to be less consistent than other company activities, especially CA association (e.g., Sen \& Bhattacharya, 2001). However, little research examines what factors could cause the lack of consistent main effect of CSR association (c.f., He \& Yi, 2011). This study contributes to the explanation of CSR's inconsistent effect by showing that CSR has a weaker effect on organizational legitimacy when performative action the company is low.

\subsection{Limitation and Future Research}

While this research provides theoretical and managerial implications, it is not without limitations. First, this study used three different general merchandise retailers with a physical store presence to prompt their responses to the survey measurements. This may provide limited implications to other retail industries such as specialty stores (e.g., Gap), service brands (e.g., T-Mobile), or purely online retailers (e.g., Amazon). Future researchers might want to replicate and compare current research results with other retail sectors or platforms to test the CSR action and its effect in the institutional environment.

As the main objective of this study was to highlight the effect of CSR and performative actions and their joint effect on social and financial gains within the institutional environment, we operationalized the constructs to be uni-dimensional. In future studies, a multi-dimensional approach to research constructs would aid in furthering the understanding of the given phenomena. 


\section{References}

Anagnostou, A., Ingenbleek, P. T. M., \& van Trijp, H. C. M. (2015). Sustainability labeling as a challenge to legitimacy: Spillover effects of organic Fairtrade coffee on consumer perceptions of mainstream products and retailers. The Journal of Consumer Marketing, 32(6), 422-431. https://doi.org/10.1108/JCM-11-2014-1213

Anderson, J. C., \& Gerbing, D. W. (1988). Structural equation modeling in practice: A review and recommended two-step approach. Psychological Bulletin, 103(3), 411-423. https://doi.org/10.1037/0033-2909.103.3.411

Anderson, P. (1982). Marketing strategic planning and the theory of the firm. Journal of Marketing, 46, 15-26. https://doi.org/10.1177/002224298204600203

Armstrong, J. S., \& Overton, T. S. (1977). Estimating nonresponse bias in mail surveys. Journal of Marketing Research, 14(3), 396-402. https://doi.org/10.1177/002224377701400320

Arnold, S. J., Handelman, J. M., \& Tigert, D. (1996). Organizational legitimacy and retail store patronage. Journal of Business Research, 35(3), 229-239. https://doi.org/10.1016/0148-2963(95)00128-X

Arnold, S. J., Kozinets, R. V., \& Handelman, J. M. (2001). Hometown ideology and retailer legitimation: The institutional semiotics of Wal-Mart flyers. Journal of Business Research, 77, 243-271. https://doi.org/10.1016/S0022-4359(01)00046-X

Ashforth, B. E., \& Gibbs, B. W. (1990). The double-edge of organizational legitimation. Organization Science, 1, 177-194. https://doi.org/10.1287/orsc.1.2.177

Berens, G., van Riel, C. B. M., \& van Bruggen, G. H. (2005). Corporate associations and consumer product responses: The moderating role of corporate brand dominance. Journal of Marketing, 69(3), 35-48. https://doi.org/10.1509/jmkg.69.3.35.66357

Berry, L. L., Seiders, K., \& Gresham, L. G. (1997). For love and money: The common traits of successful retailers. Organizational Dynamics, 26(2), 7-23. https://doi.org/10.1016/S0090-2616(97)90002-4

Bhattacharya, C., Korschun, D., \& Sen, S. (2009). Strengthening stakeholder-company relationships through mutually beneficial corporate social responsibility initiatives. Journal of Business Ethics, 85(S2), 257-272. https://doi.org/10.1007/s10551-008-9730-3

Bollen, K. A., \& Long, J. S. (1992). Tests for structural equation models. Sociological Methods \& Research, 21, 123-282. https://doi.org/10.1177/0049124192021002001

Brown, T. J., \& Dacin, P. A. (1997). The company and the product: Corporate associations and consumer product responses. Journal of Marketing, 61(1), 68-84. https://doi.org/10.1177/002224299706100106

Cheit, E. F. (1964). Why managers cultivate social responsibility, In J. G. Maurer (Ed.), Readings in organization theory: Open-systems approaches (pp. 365-390). New York, NY: Random House.

Deegan, C. (2009). Financial accounting theory. North Ryde, Australia: McGraw Hill.

DiMaggio, P. J. (1988). Interest and agency in institutional theory. In L. Zucker (Ed.), Institutional patterns and organizations: Culture and environment (pp. 3-22). Cambridge, MA: Ballinger.

DiMaggio, P. J., \& Powell, W. W. (1991). The new institutionalism in organizational analysis. Chicago, IL: University of Chicago Press.

Dowling, J., \& Pfeffer, J. (1975). Organizational legitimacy: Social values and organizational behavior. The Pacific Sociological Review, 18(1), 122-136. https://doi.org/10.2307/1388226

Elsbach, R. M. (1994). Managing organizational legitimacy in the California cattle industry. Administrative Science Quarterly, 39(1), 57-88. https://doi.org/10.2307/2393494

Fornell, C., \& Larcker, D. F. (1981). Evaluating structural equation models with unobservable variables and measurement error. Journal of Marketing Research, 18(1), 39-50. https://doi.org/10.1177/002224378101800104

Gurhan-Canli, Z., \& Batra, R. (2004). When corporate image affects product evaluations: The moderating role of perceived risk. Journal of Marketing Research, 41(2), 197-205. https://doi.org/10.1509/jmkr.41.2.197.28667

Hall, P. A., \& Taylor, R. C. R. (1996). Political Science and the three new institutionalisms. Political Studies, 44(5), 936-957. https://doi.org/10.1111/j.1467-9248.1996.tb00343.x 
Handelman, M., \& Arnold, S. J. (1999). The role of marketing actions with a social dimension: Appeals to the institutional environment. Journal of Marketing, 63(3), 33-48. https://doi.org/10.1177/002224299906300303

He, H., \& Balmer, J. M. T. (2007). Identity studies: Multiple perspectives and implications for corporate level marketing. European Journal of Marketing, 41(7/8), 765-785. https://doi.org/10.1108/03090560710752393

Heikkila, T., \& Isett, K. R. (2004). Modeling operational decision making in public organizations. American Review of Public Administration, 34(1), 3-19. https://doi.org/10.1177/0275074003260911

Hildebrand, D., DeMotta, Y., Sen, S., \& Valenzuela, A. (2017). Consumer responses to Corporate Social Responsibility (CSR) contribution type. Journal of Consumer Research, 44(4), 738-758. https://doi.org/10.1093/jcr/ucx063

Klein, J., \& Dawar, N. (2004). Corporate social responsibility and consumers' attributions and brand evaluations in a product-harm crisis. International Journal of Research in Marketing, 21(3), 203-217. https://doi.org/10.1016/j.ijresmar.2003.12.003

Knox, S., \& Bickerton, D. (2003). The six conventions of corporate branding. European Journal of Marketing, 37(7/8), 998-1016. https://doi.org/10.1108/03090560310477636

Lichtenstein, D. R., Drumwright, M., \& Braig, B. M. (2004). The effect of corporate social responsibility on customer donations to corporate-supported nonprofits. Journal of Marketing, 68(4), 16-32. https://doi.org/10.1509/jmkg.68.4.16.42726

Luo, X., \& Bhattacharya, C. B. (2006). Corporate social responsibility, customer satisfaction, and market value. Journal of Marketing, 70(4), 1-18. https://doi.org/10.1509/jmkg.70.4.001

MacCallum, R. (1986). Specification searches in covariance structure modeling. Psychological Bulletin, 100(1), 107-120. https://doi.org/10.1037/0033-2909.100.1.107

Marin, L., \& Ruiz, S. (2007). "I Need You Too!": Corporate identity attractiveness for consumers and the role of social responsibility. Journal of Business Ethics, 71(3), 245-260. https://doi.org/10.1007/s10551-006-9137-y

Meyer, J. W., \& Scott, W. R. (1992). Centralization and the legitimacy problems of local government. In J. W. Meyer \& W. R. Scott (Eds.), Organizational environments: Ritual and rationality (pp. 1-5). Beverly Hills, CA: Sage.

Milliman, J., Ferguson, J., \& Sylvester, K. (2008), Implementation of Michael Porter's strategic Corporate Social Responsibility model. The Journal of Global Business Issues (Conference ed.), 29-33.

Mohr, L. A., Webb, D. J., \& Harris, K. E. (2001). Do consumers expect companies to be socially responsible? The impact of corporate social responsibility on buying behavior. Journal of Consumer Affair, 35, 45-72. https://doi.org/10.1111/j.1745-6606.2001.tb00102.x

Oliver, R. L. (1997). Satisfaction: A behavior perspective on the customer. New York: Irwin/McGraw-Hill.

Parsons, T. (1960). Structure and process in modern societies. New York, NY: Free Press.

Ping, R. A. Jr. (1995). A parsimonious estimating technique for interaction and quadratic latent variables. Journal of Marketing Research, 32(3), 336-347. https://doi.org/10.1177/002224379503200308

Rangan, V. K., Chase, L., \& Karim, S. (2015). The truth about CSR. Harvard Business Review, 93(1/2), 35-38. https://doi.org/10.1093/acprof:oso/9780198744283.003.0007

Schlusberg, M. (1969). Corporate legitimacy and social responsibility: The role of law. California Management Review, 12, 65-76. https://doi.org/10.2307/41164207

Scott, W. R. (1987). The adolescence of institutional theory. Administrative Science Quarterly, 32, 493-511. https://doi.org/10.2307/2392880

Sen, S., \& Bhattacharya, C. B. (2001). Does doing good always lead to doing better? Consumer reactions to corporate social responsibility. Journal of Marketing Research, 38(2), 225-243. https://doi.org/10.1509/jmkr.38.2.225.18838

Sen, S., Bhattacharya, C. B., \& Korschun, D. (2006). The role of corporate social responsibility in strengthening multiple stakeholder relationships: A field experiment. Journal of the Academy of Marketing Science, 34(2), 158-166. https://doi.org/10.1177/0092070305284978 
Srinivasan, S. S., Anderson, R., \& Ponnavolu, K. (2002). Customer loyalty in e-commerce: An exploration of its antecedents and consequences. Journal of Retailing, 27, 279-295. https://doi.org/10.1016/S0022-4359(01)00065-3

Steiger, J. H., Shapiro, A., \& Browne, M. W. (1985). On the multivariate asymptotic distribution of sequential chi-square tests. Psychometrika, 50, 253-264. https://doi.org/10.1007/BF02294104

Suchman, M. (1995). Managing legitimacy: Strategic and institutional approaches. Academy of Management Review, 20, 571-610. https://doi.org/10.5465/amr.1995.9508080331

Votaw, D., \& Sethi, S. P. (1969). Do we need a new corporate response to a changing social environment? California Management Review, 12, 3-16. https://doi.org/10.2307/41164199

Wei, W., Kim, G., Miao, L., Behnke, C., \& Almanza, B. (2018). Consumer inferences of corporate social responsibility (CSR) claims on packaged foods. Journal of Business Research, 83(2), 186-201. https://doi.org/10.1016/j.jbusres.2017.10.046

\section{Copyrights}

Copyright for this article is retained by the author, with first publication rights granted to the journal.

This is an open-access article distributed under the terms and conditions of the Creative Commons Attribution license (http://creativecommons.org/licenses/by/4.0/). 